\title{
The feasibility of using a solar power generator system in Kurdistan: Koya city as a case study
}

\author{
Hayder H. Abbas \\ Department of Chemical Engineering, Faculty of Engineering, \\ Koya University, Kurdistan Region of Iraq
}

\begin{abstract}
The first worldwide concern is "global warming" which has increased rapidly, due to many factors; the most important is dependency on a fossil fuel to feed the demand for electricity, which contributes to increasing pollution in the ecosystem. So, using a renewable energy resource, such as solar energy as an option for electric power generators is something which can't be overemphasized. The main purpose of this work is to study the feasibility of using solar energy application in Koya city to generate electricity. The approach used in this work is dependent mainly on statistical data and real life recorded data; these data being recorded for a period of one year. The experimental and analysis results show that a solar power generator system could be efficiently used to generate electricity, which is required to provide the domestic load in Koya city.
\end{abstract}

Keywords: solar energy, environmental pollution, electric power generator, domestic load, photovoltaic system.

\section{Introduction}

Energy does not only play an important role in our everyday living life, but also has an essential role in the development of industry, agriculture, medicine and all fields of human activities. There is increasing demand for electricity in Kurdistan Region (KR), due to the rapid increase in population, rising standards of living, and the immigration from other cities in Iraq to the KR due to security concern. The energy sources that are used for electricity production in KR are fossil fuels such as oil and natural gas - are known as non-renewable resources. Burning the fossil fuels can change the planet's climate and harm ecosystems, through 
gaseous emissions. However, using renewable and unconventional energy power sources will help to control, replace and avoid adverse environmental impacts [1].

Solar energy is an inexhaustible resource. The sun produces vast amounts of renewable solar energy that can be collected and converted into heat and electricity.

The importance of solar energy is outlined in the following points [2, 3]:

1. Solar energy is safe.

2. Clean and quiet to operate.

3. Solar energy requires less maintenance.

4. Provides powers independence on public electricity.

5. Solar energy is renewable and free.

The solar energy system is flexible and can be expanded without changing the original design to meet increasing electricity needs. The study area is Koya city, Koya is one of the oldest districts of Iraq since Othman era, the last Iraqi regime tried to destroy Koya and about 120 villages were removed and destroyed through the Anfal campaigns in the 80s of the last century.

Koya city is geographically located in the heart of Kurdistan of Iraq. The city is located in the north of Iraq, at $630 \mathrm{~m}$ above sea level. The total area is about $2051 \mathrm{~km}^{2}$. The city is considered as a bridge connects the governorates of Erbil, Sulaymaniyah and Kirkuk, with each other. This strategic location has enabled the city to prosper and become one of the centers of commerce, education and culture in Kurdistan. Koya city faced the same problems that which arise in Kurdistan for instance the demand for electricity and environmental degradation. The power generation is yet another problem especially the use of many thousands of small private power generators all across the cities. This in turn generates sound pollution.

Therefore, in this work we proposed the use of solar energy to generate electricity for domestic load in the Koya city to decrease the environmental degradation and to supply free energy to substitute the demand in electricity. In this work a real life application is presented and the impact on Koya city is studied.

\section{The nature of the problems}

Koya district shared the problems with Kurdistan region and global problems that deal with lack in electricity, environmental degradation, and economic issues, the three parts are described below.

\subsection{Environmental issues}

The problems of Kurdistan environment are part of the global problem, especially those related to global warming. A large percentage of forest area in the region has decreased, with increase of the negative effect of fossil fuel combustion. Electricity generators, automobiles, ovens, are continuing causes of environmental destruction in the Kurdistan environment [4]. Kurdistan region 
Carbon Dioxide Emission from 2003-2008 are 25-30 Million $\mathrm{m}^{3}$ Tons which presents the increasing in pollutant gases in Kurdistan region [5]. One of the signs about the pollution in Kurdistan environment is the existence of the black pollutants cloud that is sometimes over the city (Hawler). These pollutants are causing medical concern for the population in the city, this is due to the lack of rules, legislations and policies protect the environment of Kurdistan [6]. Although, there is no industry in Kurdistan, the huge number of power generators that are producing electricity and high number of cars, are contributing to high concentration of $\mathrm{CO}^{2}$ and causing greenhouse effect in the city [6]. Koya city as a part of Kurdistan/Erbil contributes to the air pollution and acid rain with adverse effect on soil and plants. From Fig. 1, it is clear that the region has depended on fossil fuel to generate electricity with a small percentage using renewable energy.

\section{Electric Power Generation(Kurdistan)}

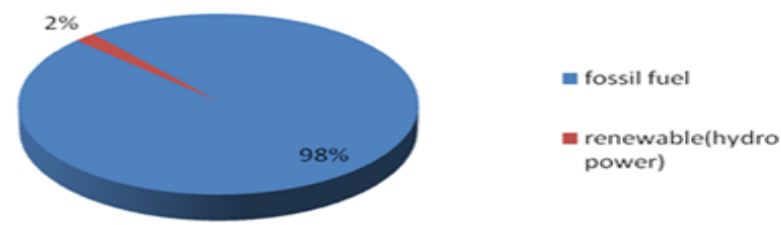

Figure 1: The percentage of fossil fuel with respect to non-conventional forms of energy [3].

\subsection{Electricity demand issue}

Due to an increase in stability in the area and immigration from rural area and from the south of Iraq, the KR has experienced rapid increases in electricity demand. The electricity system in the Koya city requires rehabilitation, reinforcement and development in order to provide adequate and reliable power to the existing consumers and to cater for the connection of new consumers. The existing master plan for the electricity which done by the Ministry of Electricity (MoE) are not satisfied the demand in the region, Koya city as a part of Kurdistan share this shortage in electricity.” Iraqis went on a buying spree of consumer products, and still have large subsidies so power usage went up just as fast” [7]. For instance, table 1 shows the existing and planned generators.

\subsection{Economic issues}

Nobody can deny that the importance of the energy sector in economic growth, without energy it will be difficult to achieve the development process, therefore, the role of renewable energy play an essential role in the energy sector. In Koya city the electric consumers are divided into five category commercial, industrial, agriculture, governmental, and domestic (as shown in Fig. 2). 
Table 1: $\quad$ The lack of electricity in the Kurdistan region [3].

\begin{tabular}{|l|l|l|l|l|l|l|l|}
\hline Years & $\mathbf{2 0 0 9}$ & $\mathbf{2 0 1 0}$ & $\mathbf{2 0 1 1}$ & $\mathbf{2 0 1 2}$ & $\mathbf{2 0 1 3}$ & $\mathbf{2 0 1 4}$ & $\mathbf{2 0 1 5}$ \\
\hline $\begin{array}{l}\text { Existing power } \\
\text { plants* }\end{array}$ & 1850 & 2050 & 2250 & 2450 & 2650 & 2650 & 2850 \\
\hline $\begin{array}{l}\text { Projected demand } \\
\text { load* }\end{array}$ & 1986 & 2204 & 2446 & 2642 & 2774 & 2913 & 3059 \\
\hline Shortage power* & -136 & -154 & -196 & -192 & -124 & -263 & -209 \\
\hline
\end{tabular}

*All values in Megawatt (MW).

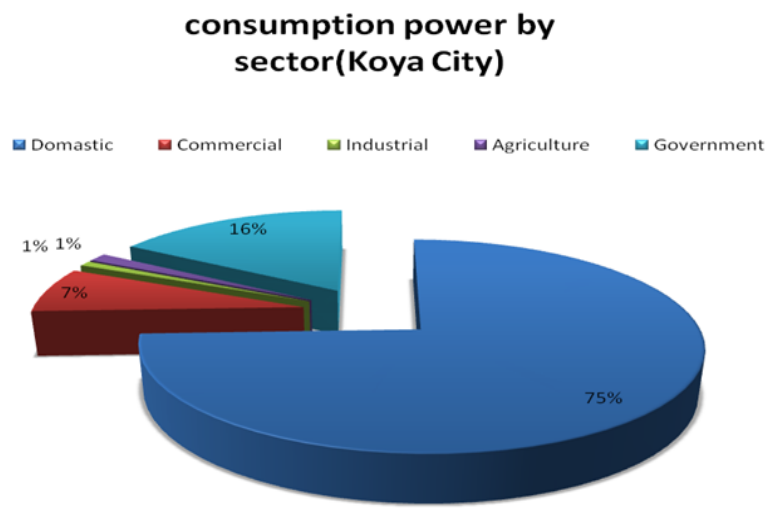

Figure 2: $\quad$ Consumption power by sectors of Koya city [4].

The consumed electric power is dominated by the domestic load which is $75 \%$ of the total consumption of energy in the city. For instance, in 2009, the consumed power for domestic load is $16.3 \mathrm{MW} / \mathrm{h}$ and the net cost of this power is 81.2 million Iraqi Diners (ID) per month [3].

\section{Electric energy situation in Koya city}

\subsection{Electricity consumption}

The statistical data from MoE presents that in Koya city the electricity demand sector is dominated by domestic consumers. Table 2 shows the percentage of consumers and category in Koya city starting from 2007 to 2009.

As was mentioned above, the market for electricity is dominated by the domestic customers. It has been mentioned that many domestic consumers' use of energy is not metered and the actual figures above are on a (severely suppressed) replacement with (conservative estimates) basis. In particular, they exclude supplies from self-generation and private contractors. 
Table 2: $\quad$ Category and percent of consumers in Koya [3].

\begin{tabular}{|c|c|c|c|c|c|}
\hline Years & Domestic & Commercial & Industrial & Agriculture & Governmental \\
\hline $\mathbf{2 0 0 7}$ & $87 \%$ & $10 \%$ & $1 \%$ & $0 \%$ & $2 \%$ \\
\hline $\mathbf{2 0 0 8}$ & $88 \%$ & $10 \%$ & $1 \%$ & $0 \%$ & $1 \%$ \\
\hline $\mathbf{2 0 0 9}$ & $88 \%$ & $9 \%$ & $1 \%$ & $0 \%$ & $2 \%$ \\
\hline
\end{tabular}

\subsection{Private generators}

The private generators were proposed by MoE KRG, as a fast solution for increasing power demand and covering the shortage of electricity in the region. In Koya city there are 32 private generators distributed in the neighborhoods and there are 12,489 consumers in private power generators, the amount of sharing current are varying from 1-5 Ampere/month (as shown in Fig. 3). From this figure it is clear that $50 \%$ of consumers are requiring $2 \mathrm{~A}$ and $43 \%$ are using $3 \mathrm{~A}$. The numbers of consumers requiring 4-5 Ampere are very small (approximately $1 \%)$; the majority of those consumers are government and commercial sectors.

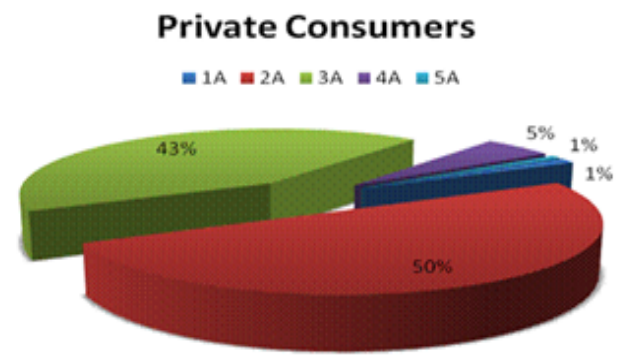

Figure 3: The private generator consumers in Koya city [3].

\section{The proposed solution}

Every change begins with a vision and a decision to take an action, our vision is using solar energy to generate electricity in the Koya city for domestic load which represents $75 \%$ of the total consumption of power in the city. Our proposed system composed of a photovoltaic (PV) system (SM-36 manufactured by Siemens) to generate electricity by using a real life database which recorded by [3]. The data of PV system were taken during a one year period three to four times per week, and twelve to thirteen times per month. These data, composed of current, voltage, and power, were recorded in the study area. These data can be used to validate the potential of use a PV system to generate electricity in Koya city. The proposed system is supply $3 \mathrm{~A} / \mathrm{h}$ which covered $95 \%$ of private electric consumers from private generators. Table 3 shows that the required PV modules numbers and area required to supply 1,2 , and 3 amperes. 
Table 3: $\quad$ The required current and corresponding PV’s Number.

\begin{tabular}{|c|c|c|c|}
\hline $\begin{array}{c}\text { Required } \\
\text { current (I) }\end{array}$ & $\begin{array}{c}\text { Power } \\
(\mathrm{KW})\end{array}$ & $\begin{array}{c}\text { Area of PV } \\
\text { Module }\left(\mathrm{m}^{2}\right)\end{array}$ & $\begin{array}{c}\text { Number of PV } \\
\text { Module }\end{array}$ \\
\hline 1 & 0.198 & 10 & 20 \\
\hline 2 & 0.396 & 20 & 40 \\
\hline 3 & 1.198 & 30 & 60 \\
\hline
\end{tabular}

For economic purposes, we proposed solar system sized so that it can provide $1 \mathrm{KW}$ of power for 6 hours per day. From the local market the price of PV calculates as $\$ 3.5 / \mathrm{W}$, and the operation life of a PV system (24 yrs), and for batteries the price is $\$ 280$ for $500 \mathrm{~A} / \mathrm{h}$ (8 year life) the system required three batteries, wires and inverter and installation $\$ 500$. The fixed cost for $1 \mathrm{KW}$ for $24 \mathrm{yrs}=\$ 4,840$.

$$
\begin{gathered}
\mathrm{T}_{\text {cost }}=\text { Total PV cost }+ \text { Cost of Batteries }+ \text { fixed cost (inverter +installation cost) } \\
\mathrm{T}_{\text {cost }}=\$ 3.5 / \mathrm{W} * 1000 \mathrm{~W} / \mathrm{h}+\$ 280 * 3+\$ 500 \\
\left.\mathrm{~T}_{\text {cost }}=\$ 4840 / \mathrm{h} \text { (Total cost for } 24 \mathrm{yrs}\right)
\end{gathered}
$$

\section{Impact of proposed system on Koya city}

The impact of the use of solar energy in Koya city has been divided into three fields. The first field is environmental impact where the pollutant gases, sound pollution, and visual pollution are decreased in Koya city, which were produced by a huge number of private generators. Second field is economic impact where the solar energy could be considered as a free energy used to replace the private generator fee, where the Ministry of Electricity charging citizens the cost of electricity, which increases the economic load that affected the poor section of society in Koya city.

The third field is electricity demand; the proposed electric solar generator system provides electricity for the city and rural area, which improve the life standard in Koya city.

\section{Conclusion}

A real life application is presented in this work, this work is ongoing research in order to replace the depended on fossil fuels with solar energy. From the results it's clear that the study area consider rich of solar radiation, and have a good potential for electric power generator application. PV system has high capital costs and lower operating costs, the cost of the PV system will be divided into two parts, the initial investment and operating costs, from the results the cost of $1 \mathrm{KWh}$ is equal to $\$ 12 /$ month for 24 yrs. The number of PV panels depended on the power demand, and the biggest concern with solar technologies is land use. 


\section{References}

[1] Kothari, D. Renewable Energy Scenario in India. IEEE Journals, 6: 643-636, 2000.

[2] Mohammed. SH. Street and House Lighting Using PV Panel, a thesis submitted to the council of College of Engineering University of Salahaddin, 2009.

[3] Alkalefa, Sh., Abbas, H. Spatial Planning of Solar Energy Resource by Using GIS. A Diploma Thesis Faculty of Engineering Duhok University, Iraq, 2011.

[4] Ministry of Electricity KRG. Statistical Report, Retrieved August 29, 2013, from department of energy sell in Koya city.

[5] US Information Administration. $\mathrm{CO}^{2}$ emissions worldwide. Retrieved June 4, 2012, from: http://www.eia.doe.gov/oiaf/environment/emissions/carbon.

[6] Ministry of Environment KRG. Statistical Report, Retrieved May 13, 2009, from http://www.zhenga.net/english/zhengapage.php?pid=2, 2009.

[7] World Bank. Poverty Report. Retrieved May 1, 2010, from http://beta.worldbank.org/climatechange/research, 2010. 